\title{
Consciousness with Body and Soul: an Attempt at Cohen's Never-Written Psychology
}

\author{
Hans Martin Dober $₫$ \\ University of Tübingen, \\ 12, Liebermeisterstraße, Tübingen, 72076, Germany \\ هhmdober@gmx.de
}

\begin{abstract}
There are contemporary tendencies to regard the human consciousness as an algorithm, or to reduce the human subjective to organic-natural processes or to see it as a social construction depending on cultural conditions. Such approaches pose a challenge to ethical humanism, as it seems, as if it requires new justification and groundings. How can we grasp and defend the concept of embodied subjectivity of man and its freedom to act? How can we think of its unity including thought, will and feeling, preventing it from getting lost in specialized potentials, and maintaining the person as an alert, responsible and self-founded unit? Furthermore, how is it possible to preserve the meaning of the name of the soul, since the notion of this traditional limit concept of the human subjective has fallen into disuse and likely vanished from the horizon? The essay asks for answer with the help of Hermann Cohen, the great Jewish philosopher of Neo-Kantianism, following the traces of his repeatedly stated, however never written systematic psychology. This first part of investigation confines itself to understand Cohen's early interpretation of Plato as the "primordial cell" of his psychology in order to show how the first three parts of his system of philosophy (Logic, Ethics, Aesthetics) answer to some of the questions and problems the early work had raised, with special attention to Cohen's philosophy of religion. Self-movement of soul and its deep connection with the human body could be viewed and grasped from the unity of human culture as well as of the allness of man.
\end{abstract}

Keywords: consciousness, the soul, psychology, Plato, Kant, the unity of human culture

\section{Article history:}

The article was submitted on 20.05.2021

The article was accepted on 11.08.2021

(C) Dober H.M., 2021

This work is licensed under a Creative Commons Attribution 4.0 International License https://creativecommons.org/licenses/by/4.0/ 
For citation: Dober H.M. Consciousness with Body and Soul: An Attempt at Cohen's Never-Written Psychology. RUDN Journal of Philosophy. 2021;25(3):420-435. DOI: 10.22363/2313-2302-2021-25-3-420-435

\section{The question of the soul of man}

The question of what we have to understand by the soul has not grown old to this day. For a long time it threatened to disappear from the horizon of contemporary consciousness ${ }^{1}$. But in recent times, there has also been a growing attention to what the name of the soul once meant, not only in contemporary literature and $\operatorname{art}^{2}$, but also in theological research. The concept of the soul itself seems to "slip away in the face of multiple criticisms", according to the systematic theologian Jörg Dierken. But its traditional meaning still concerns the constitution of "the human subjective", provided that it can neither be reduced to "organicnatural processes", as medicine, neurology and brain research recognize them, nor to "social processes", whose mere reflex is the human, nor to a "mere nodal point of communication, which — as at present partly electronic — proceeds according to predetermined algorithms" [5. P. 2, 6. P. 199].

This assessment corresponds to the effort on the part of psychiatry and psychotherapy to regard subjectivity not only as a brain function, but from the conditions of "embodied" personality. This includes defending human beings as a "body-soul unit" [7. P. 204], even in the age of ever more comprehensive, faster data processing and so-called "artificial intelligence" up to human robotics, for whose humanity the inclusion of "systemic-ecological" interactions is indispensable [8. P. 67-79]. The name of the soul carries with it a residual meaning that is not exhausted in neural structures, digitized processes or organic-natural processes (such as biochemically describable foundations and changes).

The following considerations seek to determine this remainder with the help of Hermann Cohen. This philosopher of the Jewish faith taught from the second half of the 19th to the beginning of the 20th century in Germany (Marburg), and presided over the then powerful philosophy of Neo-Kantianism as one of its most important minds. His thinking has unfolded in a three-part system. The Logik der reinen Erkenntnis [9], the Ethik des reinen Willens [10] und the Ästhetik des reinen Gefühls [11] proceed from the three faculties attributed to the "soul" in the tradition of European thought ${ }^{3}$. A fourth part of the system was planned, which was to give an account of the "unity of the soul" [10. P. 233]: as the "unity of consciousness" [9. P. 519f., 12. P. 431]. This part should explain in theory how the soul of man can

\footnotetext{
${ }^{1}$ A sketch of this process in modern philosophy was given by H. Holzhey [1. P. 94f.]; Cf. also [2]. A thorough overview of the development of concepts is given in the article "Soul" in the Historical Dictionary of Philosophy, Vol. 9.

${ }^{2}$ The question of the soul plays a role in H. Mankell's Treibsand. Was es heißt, ein Mensch zu sein [3], but also in I. McEwan's Saturday [4], to leave it here with these two examples. From the field of film one could name: Die Bourne-Trilogie (USA 2002-2007) or Blade Runner 2049 (USA 2017). ${ }^{3}$ However, only Schleiermacher has secured the place für the feeling as an equal third fortune (see below para. 2.1).
} 
be capable of subjectively regulating the manifold processes of human cultural activity. But it has not come to the realization of this project. We do not know how this work would have been structured and executed in detail. But there are a variety of traces in the available writings that make it possible to safely substantiate key questions and contents of Cohen's early and continuing interest in psychology.

In the following, I shall confine myself to understanding the early interpretation of Plato of 1866 as the "primordial cell" of Cohen's psychology, which had been repeatedly stated in the "System der Philosophie" [13. P. 101-191] $]^{4}$, in order to show vice versa the first three parts of the system as a later answer to some of the questions and problems that the work on Platons Ideenlehre had raised. Attention should then be directed to the late philosophy of religion, which - largely developed from the historical sources of Judaism - can appear as a detour to systematic psychology $[14,15]^{5}$. I have to do without a comprehensive search for traces in the writings interpreting Kant ${ }^{6}$.

\section{The "primordial cell" of Cohen's psychology}

The soul is initially a subject of myth, and this also with Plato, who, however, through his "discovery" [13. P. 110] of the idea as an early witness, can be claimed to encounter the driving powers of the soul with the conscious forces of the spirit. He understood the soul more and more as a "spiritual principle" [15. P. 344]. This required the work of thought (explicitly appreciated by Kant [13. P. 108-110]), which, especially in the Symposium, represented the original aspiration peculiar to the human soul as such, which at the stages of natural, cultural, and spiritual life is ultimately related to the idea of good (13. P. 171, 157). Even in the late work it is said: "Primarily and first the soul stands up for thinking, and in this isolated sense for consciousness (mneme), but soon it must also be used for moral problems. Thus reason (nous) arises, which, originally conceived only as a theoretical spirit, at the same time also as moral, as practical reason becomes concise." [15. P. 344].

The original aspiration of man is rooted in his soul as the "place of ideas" [16. Book 3$]^{7}$. Although it is also determined by its drive, desires, and feelings, not only by its cognitive potential, in which, according to ancient belief, as well as in Cohen's reception, its primary competence exists. By virtue of this potential, however, it should be able to rise above all the depths of earthly existence, of existence bound to the body - as a prison ${ }^{8}$. As Cohen's later work clearly enough shows, he resists the misconception of seeing a devaluation of the body in the metaphor of

\footnotetext{
${ }^{4}$ Cf. further H. Cohen's Mythologische Vorstellungen von Gott und Seele psychologisch entwickelt; Die dichterische Phantasie und der Mechanismus des Bewusstseins [13. P. 271-343, 345-463].

${ }^{5}$ The second part of this essay will rekonstruct this detour from the later work, Religion der Vernunft aus den Quellen des Judentums [15].

${ }^{6}$ I.e. Cohen, Kants Theorie der Erfahrung (1871), Kants Begründung der Ethik (1877) und Kants Begründung der Ästhetik (1889).

${ }^{7}$ Cf. [13. P. 159] referring to Plato's Parmenides, $132 \mathrm{~b}$.

${ }^{8}$ Plato. Gorgias 493a, Kratylos 400c, Phaidros 250c.
} 
imprisonment: the works of art $^{9}$, and especially the portraits, depict the embodiment of the soul and thus confirm the later insight of religious philosophy that "the soul is bound to the body by God" [15. P. 356].

\subsection{The self-movement of the soul, framed in a picture}

Among the mythical forms of imagination that Platonic thought uses is that of the soul as a "winged one", which is able to completely overcome the bars of its physical existence only when dying, with death. It attains full freedom when the spirit rises from earthly ties into heavenly realms in order to be able to cultivate perfect communion with other spirit souls ${ }^{10}$. But already during his lifetime the soul finds itself in a middle position between cosmos and the world of ideas. This is depicted in the myth of the procession of the gods in the dialogue Phaidros. I am guided by this parable, even if it does not play a role in Cohen's early work.

This parable lends itself as a reference and focal point for many of the aspects of Platonic thought relevant to Cohen. In addition, it proves to this day that we can perhaps speak of the soul more easily in metaphors than in terms ${ }^{11}$. Plato compares it "to a winged chariot with a driver, pulled by horses. Now, while the horses of the gods are all of noble lineage, those of souls other than human have horses of mixed origin. Only the one is beautiful and noble and of appropriate breeding, but the other is of opposite quality. So even with us the steering is necessarily arduous and laborious" [17. P. 58].

Plato's concept of the soul, that it is "the self-moving"12, is here framed in the image of a chariot with a charioteer. First of all, self-movement is the principle of a living organism. In animals, this principle is determined by instincts and ritualized behavior - both also occur in humans. But, according to the beliefs of ancient Greek thinkers, not the animal, but "man is the measure of all things." [13. P. 131]. He seems to be suitable for this because his soul can be thought of as "the selfmoving" with regard to its abilities of thinking, wanting, and feeling. In the interaction of these abilities, the soul directs not only itself, but also the movements of the body.

In the metaphorical expression of the wings, therefore, the original thought, which is absolutely leitmotif for Cohen, can be recognized that the discovery of the idea has become possible only because of the self-origin (as self-movement) of thought [13. P. 104 et al.]. Since this is later taken strictly as the foundation of the hypothesis (a notion that only Kant developed to full transparency), Cohen frees the thought from the mythical idea that the striving of the soul extends into a sphere between human and worldly things.

\footnotetext{
${ }^{9}$ See below para. 3.3.1. footnote 28 .

${ }^{10}$ Platon, Phaidros 250a.

${ }^{11} \mathrm{Cf}$. para 6.2. in part II of the essay.

${ }^{12}$ After Cohen's [13. P. 184] referring to Phaidros 245. Cf. Aristoteles, De Anima I, 2.
} 
On the narrative path taken by Plato, however, it can also be seen to what extent the principle of self-movement is a "terminus of ethics"13 for Cohen [13. P. 184]. For the will also moves itself, in that, following the later Ethics of the pure will, it determines itself as a free person to autonomy. In order to remain in the picture, it is now up to the "driver" as the ethical self of $\operatorname{man}^{14}$ to move the will in a team with the other horses (i.e. the drives, desires, longing) as a guiding animal on the journey of individual life. In this way, it is important to strive for something higher, for the true, beautiful, and good, however arduous the control of the forces may be that bind the soul to the physical existence of man. "Only the soul wants; the body desires", it says in the late work. "Only the soul is capable of good; only the soul thinks the idea of good, and only it itself with its will is able to carry out good; only it alone is capable of action. Only it has reason and is reason in the dual sense of theoretical and practical reason." [15. P. 388 $]^{15}$.

Plato wanted to find the "epitome of consciousness" [15. P. 390] in the concept of the soul. But there is still a lack of feeling as a third soul capacity or as a third form of consciousness, which - according to the philosophy of religion - only Schleiermacher had helped to achieve full knowledge by making it native to religion. "It must not be doubted that he [Schleiermacher], by drawing religion into the consciousness, has made progress over Kant ... In that Schleiermacher now raised religion into the consciousness of man, he brought it into the coordination of knowledge and philosophy." [14. P. 94f.]. We shall see how Cohen's systematic philosophy attempts to correct the error that Schleiermacher made in mixing religious and aesthetic feeling in an improper way. In order to distinguish the two clearly enough, Cohen assigns feeling as a form of consciousness to aesthetics. Here he is assured of his permanent place in the "system of philosophy", while religion in its "peculiarity" [Eigenart] is not treated as part of it. Psychology, however, should have fulfilled the claim, already laid out in the Platonic concept of the soul, to represent the "unity of consciousness" as "a balance of [the] movements", which constitutes consciousness as "movement" in each of its types - cognition, will and feeling. [12. P. 420f.]

\subsection{Poetry and thought correlatively refer to each other}

By analogy, with the eye as the most "sun-like" of the sense organs, Plato, as a thinker, "looked" at the thought [13. P. 174] ${ }^{16}$. What is meant is "conceptual

\footnotetext{
${ }^{13}$ Cf. [13. p. 131] referring to Theaitet 152a.

14 "Mit diesem Grundwort der klassischen Antike hat sich das Grundwort der neuern Zeit und der neuern Philosophie verbunden und vermählt, so dass das Bewusstsein zum Selbstbewusstsein wurde." [10. P. 325].

${ }^{15}$ This double sense is summarized in Ethics as follows: "Die Seele ist Selbstbewegung, das bedeutet uns: die Bewegung hat ihren Ursprung in sich selbst; das heißt: sie ist rein, wie das reine Denken. Aber das reine Denken erschöpft den Begriff der Seele, den Begriff des Bewusstseins nicht. Wohlan, die Seele ist auch Wille. Und der Wille ist auch Bewegung. Auch diese seelische Bewegung ist Selbstbewegung; muss ihren Ursprung in sich selbst haben" [10. P. 132].

${ }^{16}$ Cit. Politeia VI, 508b, 509a.
} 
seeing, seeing in thought, in abstraction, thinking contemplation, theory" [13. P. 137]. But also this seeing has a mental image in mind (to speak with the later aesthetics): "The images are ... appearances; and the appearances are not archetypes, primordial things, things in themselves correlative, but formations of pure thinking, Noumena. All being has its final reason in thinking. And thinking has its deepest expression in internalizing (innoein)..." [11. P. 387f.]. The image as form is thus spiritualized into the idea "as form" in order to be able to recognize images as images in return. Cohen summarizes this development as follows: "From the image, as the form, ... the idea, at first as a form, emerged ... according to the direction of the appearance [this was then] internalized into the facial image, and in this way ever more deeply matured into the spiritual vision ... the idea has become the methodical foundation for everything that claims reality as an image, as an appearance" [11. P. 22].

According to this theory, Plato as a poet then gave his "critical idealism" but also a "mythical expression" by translating the thought back into its pictorial form as a metaphor, parable or narrative [13. P. 178]. The figurative expression illustrates the thought through transmission, but always also requires interpretation in order to bring the metaphor to its point. Thus, in the parable of the charioteer, the overriding principle comes into effect, which means the soul vis-à-vis the body: the soul is the "charioteer" of the body: "without the guiding power of the soul, man cannot rise above the animal" [11. P. 299], conducting as will (cf. [15. P. 388]) and as knowledge, but also as feeling, as psychology would have had to show. This cybernetic signature, according to which the soul is responsible for the art of steering, has persisted up to Schleiermacher and (despite the transformation of the conditions in his thinking) also to Freud ${ }^{17}$. Even Cohen's insight, verified by Michelangelo, that the soul of his figures "builds itself its body; it is not the creature of a body; it is its maker" [12. P. 305], adheres to the priority of the soul over the body.

But the myth of the charioteer also carries all the aspects of Platonic thought problematic for retrospective reception - which may have made history more effective than the ideas. This includes the idea of a world soul, "which in its purposeful harmony forms the basis of all events" [13. P. 185 $]^{18}$, and this especially embedded in the myth of the demiurge who created it [13. P. 189]. It is interrelated with the individual soul by virtue of the principle of life, for "in fact, that [moving itself] means nothing other than ... [living]" [Ibid.]. The cosmos is also alive, because it is credited with the "power of self-movement". "The principle of motion equal to that of life" is the property in which individual and world souls agree

\footnotetext{
${ }^{17}$ For Schleiermacher, the self-activity of consciousness is the guiding concept for the living soul, even if "die Seelentätigkeit ... als ein Inneres ... zusammen mit organischen leiblichen Tätigkeiten zustande[kommt]" ([18. P. 77.] cit. Schleiermacher, Psychologie). And according to Freud "the I must be the master in his own house" (muss "das Ich Herr im eigenen Hause" sein) cf. [19. P. 11]. ${ }^{18}$ The late work will deal with the immortality of the soul [13. P. 186]: see below para.4.7. in part II of this essay.
} 
[13. P. 186]. In his later work, Cohen will return to the concept of the soul as the "principle of life" and "principle of the unity of the person" [15. P. 288] in order to place both provisions in the context of his Messianism.

Another problematic point for Cohen is the transformation of the original discovery of the idea as a hypothesis for all processes of cognition into a substance [13. P. 139, 167]. For indeed, "Plato ... seems to assert the idea of good as a presuppositional, unsubstantiated (anhypotheton)." [20. P. 52]. As the myth of the charioteer clearly enough expresses it, the idea here has become an "in and of itself in constant immutability existing entity" [13. P. 169]: hypostasized [=objectified] to an "absolute view" [13. P. 168], be it divine, be it earthly, or human. Between these a difference of value is introduced, according to which the one is a "noble tribe", but the other is of "mixed origin", i.e. the human soul is able to rise into heavenly spheres by means of the ideas it can think, but is kept in the lower spheres by means of its physical bond. Therefore, the steering of the horse team soul is also "arduous and laborious".

It is decisive for Cohen's understanding of Plato that poetry and thought have the same psychic root [13. P. 180f.], however different these productive capacities of man (which concern knowledge on the one hand, imagination on the other) are, and however strictly they must be distinguished. Cohen later took this thesis into account in the form of his systematic philosophy, distinguishing logic and aesthetics, but wanting to grasp both "directions" of consciousness as "unity" in psychology. In the early work focused here, however, his specific interest lies in the "psychological" conditions under which Plato, as the authoritative thinker, in turn clothed the thought that flashed in its purity in - so to speak impure mythical forms. Cohen has proposed a psychological explanation for this. Plato had made a discovery with his original concept of the idea, but without being able to achieve it "completely and with full critical insight" [13. P. 140]. This discovery had been like a "quick flash of thought", "which penetrated his mind like a sudden idea" [Ibid.], but he had not been able to hold it in its purity (and i.e. in its strictly methodical meaning for cognition), as if the potential for this had been exhausted in the economy of the soul forces.

\section{Interaction of system parts as traces to psychology}

Cohen wanted to write a systematic psychology. In view of the methodological plurality associated with this term today, it is not easy to see what he intended to do with it. He was not interested in an empirical or therapeutic doctrine of the soul, although both aspects play into his reflections. Understanding Kant from Plato and interpreting Plato with Kant, Cohen followed his method of critical idealism, according to which, the knowledge of phenomena must be derived from the selfactivity of thought. In dealing with psychic phenomena, this has the consequence that they cannot be traced back to a naturalistically conceived soul. Cohen's systematic psychology would have worked critically on patterns of explanation and interpretation that question the independence, freedom and self-activity of the soul 
through deterministic models. On the other hand, he would also have sought to preserve this subjective-personal center of the whole, undivided man from all onesidedness, as if the signum humanum could only exist in one of the three classical soul faculties cognition, will and feeling which Cohen deals with in Logic, Ethics and Aesthetics. As can be shown below, each part of the system refers to the other two, but this reference system should find its summary in psychology.

\subsection{The reference of logic to psychology}

Guided by a strong interest in countering the constant danger of unfair mixing by clear distinctions, Logic (1902) — quite in accordance with its title - refers "thought exclusively to knowledge". This is said against the so-called "psychologism", which in turn "levels cognition into a process of consciousness", thereby causing a "mishmash of problems" [9. P. 36]. For Logik der reinen Erkenntnis, this decision means, on the one hand, the claim to "produce the foundations" which, in strictly methodological terms - as "foundations to be demanded" [9. P. 260, 10. P. 97, 11. P. 248] - have a fundamental function for the other parts of the system of philosophy [9. P. 37], including psychology: psychology is not able to "produce the laws of thought" which it naturally makes use of, and which, as purely produced, are not originally related to objects such as consciousness. Knowledge finds "no hold in the presuppositional" [20. P. 52], which could be metaphysically thought of as an "absolute", be it theologically "as God" (Ibid.) or psychologically as a drive. For Cohen, it finds support only in the "idea of hypothesis", further developed "to the judgment and logic of origin" as the "center in the foundation of logic" [9. P. 513].

On the other hand, Logic "expressly renounces the unity of consciousness" [9. P. 518], although it does provide the concept of unity with the help of which psychology is supposed to undertake its task. In different ways, Ethics and Aesthetics will relate to the world of objects: the one will develop a highly reflected consciousness of the complexity of human orientation in will-directed action, the other of the experience of art in a feeling that must engage with itself both on the side of the artist and on that of the recipient. The tripartite division of the system also contradicts "the basic idea of the information age" [7. P. 27] that consciousness can be reduced to logical thought processes, so that "all our knowledge of the world is composed of individual elements or context-free features that are linked together by formal, algorithmic rules". [7. P. 28] "Mind or sense" only results from data when one consciously deals with them - through judgment. This presupposes a human subject who has consciousness. For Cohen, however, processes of consciousness are also "embodied life achievements" [7. P. 215]. But to explain this remains reserved for his aesthetics (while Thomas Fuchs argues in the horizon of a psychiatrically formed philosophical anthropology).

The systematic thinker Cohen is concerned with the "unity" of consciousness, which does not produce logic, ethics or aesthetics in itself, but which is made "a problem" for psychology [9. P. 518]: it "alone has as its exclusive content the 
subject, the unity of human culture" [9. P. 16]. On the threshold of the Ethics of the pure will, this human subject comes into view as an agent, which - guided by free will in autonomy - orients itself on the doctrine of virtue. But if it wants to live its whole humanity, this human subject is at the same time a productive and receptive one, who makes and listens to music, paints and looks at paintings, writes poems, narratives, or novels and reads them. In order to know what it experiences, and to reflect diffuse experiences on their human core, the Aesthetics of pure feeling gives orientation.

In all this, man is the subject of experience as well as responsibility, and his consciousness "not an algorithm" [7. P. 51]. But because he can get lost in the fullness of the possibilities that culture offers him and lose himself in the specializations as a whole person ${ }^{19}$, the question of the "unity of man" must be asked. [9. P. 520] Such a unity to be demanded by the human subject, but also to be brought about by itself - corresponding to the procedural character of the foundations - is conceivable, however, as a work in progress through the areas of cultural life whose theories elaborate the system parts.

This process of a constant search for unity has not yet been brought to a conclusion. In a way, it has to start again and again in the life story of an individual. Here it is important to preserve diversity and at the same time to relate the differences to each other: "the different types of laws and contents should not be extinguished in their diversity and transformed into a new type of law and contents", but the "diversity [of the cultural areas] should assert itself freely and powerfully against each other, ... [so] that nevertheless this diversity in a new, the actual unity reaches reconciliation and marriage" [Ibid.]

Without explicitly mentioning it here, the model of correlation of difference seems to carry this outlook, a model that could be supplemented by a mutual resonance, force of which logical and ethical perspectives resonate in Aesthetics, aesthetic and ethical already in Logic, and logical as well as aesthetic in Ethics (cf. [23]). If this were the case, the human soul would be understood - quite in accordance with the testimonies of the Hebrew Bible - as an inner resonance relationship (involving the corporeality of man), which at the same time stands with the outside world in the most diverse vibrations, which include dissonances: in a dialogue, so to speak, which cannot end. Psychology would therefore have to show how knowledge, will and feeling are to be related to each other in order to steadily tread the path to the unity of these three. Surprisingly, this first attempt at its phantom image corresponds to recent neurological insights: "We know today that it is by no means localized neural processes that underlie the activity of consciousness, but widely distributed resonant vibrations ... The brain is not a control center, but a resonant and relational organ" [7. P. 40f.].

\footnotetext{
${ }^{19}$ This, according to G. Simmel, is the "tragedy of culture", if one does not succeed in the challenge to bring different spheres and perspectives into conversation with each other [21]; cf. E. Cassirer, Die "Tragödie der Kultur" [22. P. 114-116].
} 


\subsection{The reference of ethics to psychology}

\subsubsection{The foundation of ethics}

The Ethics of Pure Will (1907), published five years later, also seeks to preserve its foundation from natural determinism. It does not "start from the psyche", nor is it "centered" on it, but rather makes this "ambiguous word ... a problem" [10. P. 99]. This contradicts the "naturalists of affect", who are able to "think of the moral law only as a natural law"20, but not as a law that free will gives itself autonomously. As the "ethics of the self makes [it] sovereign over [empirical] psychology" [10. P. 340] (italics by H.M.D.) by determining the concept of the will not from the "immediate facts of nature" "drive and desire", but taking into account what the will is directed at: the action [10. P. 103]. The ethical imperative of Kant act at all times in such a way that..., however, requires a foundation with the means of practical reason. This leads "to thinking and to judgment" [10. P. 125]. ${ }^{21}$

"The morale [das Sittliche]", is not "innate" [10. P. 50]. Having become part of historical processes in which myth and religion took part ${ }^{22}$, it has to be reappropriated, even transformed, again and again through the formation of the will. In other words, the a priori foundation of ethics is the guide, the benchmark and the corrective in all aposteriori considerations that concern the historical perspective of the genealogy of morality. Not in the shadow of this perspective, but through it, the will has to purify itself in order to be able to deal with freedom [7. P. 202], to "decide and act" in the tradition of Kant. Today, however, freedom must justify itself under the "dominance of scientific and scientistic thought" [7. P. 229].

Psychology cannot justify freedom. But the powers of drive and desire, with which it has to deal analytically (cf. [10. P. 103]), do not lose their supporting function for the will. The affects are sublimated (one can say interpreting) to the feeling that accompanies and carries the will. This "sense of will" remains the "motor" which "must not be lacking and must not fail" [10. P. 199, 207, 476, 480] $]^{23}$. It gives "the emotional impetus", but cannot replace the "motive" of the action, which is determined by its "spiritual content" [10. P. 199]. Thus, psychology retains its meaning and function for the self-assurance of the knowing, wanting, and feeling person. "From the great variety of psychic processes it has to establish the unity of consciousness, and in it the unity of the subject" [10. P. 75], in order in this way to

${ }^{20}$ Cf. [10. P. 99]. "Naturalism" and "supranaturalism" "do not do justice to the intrinsic value of moral being" [10. P. 28]. But this is not to be determined by the will alone - and be it by the will to power - but by including the "intellect". In Cohen's case, this can be seen in the way the will orients itself in accordance with the rational moral law — in the good Kantian tradition. See chapters $4-7$ in the [10].

${ }^{21}$ Even "from self-consciousness" the will cannot and should not be derived, if one would then accept consciousness and self-consciousness "as existing". But this is not the case when the following applies: "even self-consciousness has to be generated by the will" [10. P. 136]: like the finding of truth, becoming aware of oneself is a process that cannot end.

22 "Es ist alles Mythologie, was in der Religion nicht auf Sittlichkeit gegründet ist" [10. P. 524].

${ }^{23}$ If one compares the metaphor of the "engine" with that of the "driving force" in Kant, the changed social conditions towards the industrial age seem to be reflected in this choice. 
win again and again the continuity of the individual soul life in its historicity, however discontinuous the experience may be. In the work on his unification, the subject can cultivate a lively approach to the memories accompanying his conscious activity, while at the same time keeping the future open as a space of possibilities. ${ }^{24}$

\subsubsection{The "virtue of the sense of humanity"25 as a bridge between ethics and aesthetics}

To this continuity, however, the virtues provide orientation. All in all, they can be understood as "signposts" [10. P. 501], which, however, sometimes point in different directions. Therefore, they must be kept in conversation with each other, which counteracts directional diffusion. In this task, "truthfulness" [10. P. 498ff.] plays a key role: it "shall be the guiding principle, the rod, and the staff in every situation of life", "however eventful it may be to want and to act." [10. P. 522] In order to keep the direction as a wanderer through the area of his own life which is yet to be opened up as a future - "his whole mind, all the forces of his mind and heart" must be involved, as Cohen puts it in response to Deuteronomy 6,4 ff. Here the "Sh'ma Israel" is tacitly referred to the "Adam", the human being in general, in order to realize the "uniformity of his being" in such a way that this "is reflected in all actions as in one action." [10. P. 522]

But what else is needed for the "virtue of the sense of humanity"26, into which less Ethics itself, rather than Aesthetics, first practices? At the limit of ethics, the will that aims at action now withdraws a little, in order to turn to the "uniformity of the human race [des Menschengeschlechts]", which art "represents in the aesthetic feelings." [10. P. 637] Thanks to a "restless energy and productivity of mind and spirit", the arts raise the "human level" — and therein lies a "consolation" for humanity [10. P. 636]. While in all interest- and will-guided actions the "unity of humanity" remains mostly shadowed, even if it is intended, art makes it "obvious" by the fact that it - as "real" - represents "nationality and humanity" without contradiction in "most intimate harmony" as a unity [10. P. 636]: everything particular, special, also the "great variety of psychic processes" [10. P. 75] in the light of the feeling of humanity. Thus, the "virtue of the sense of humanity" finds its mirror in the "humanity of art". For in it "a kind of realization can be discerned for the fundamental content of ethics, for moral self-consciousness" [10. P. 636].

On the threshold of Aesthetics, the next door is already coming into view: to represent the "macrocosm of humanity, which has become visible in art, in the microcosm of man in culture, that is the great task of psychology." [10. P. 637] With this microcosm the soul of man is addressed - quite similar to how the

\footnotetext{
${ }^{24} \mathrm{Cf}$. on openness to the future: [7. P. 230], and on the importance of memory for the integrity of an individual soul life, the above-mentioned examples from contemporary film and Mankell's life memories (see note 2 above). In fact, memory is already a topic of Platonic philosophy, but the Platonic anamnesis refers to archetypes that the soul can recognize on the basis of the images - and these archetypes are not (yet) biographically connoted.

${ }^{25}$ In German: "Tugend des Menschengefühls" [10. P. 636].

26 "Der reine Wille ... [errichtet diese Tugend als] seine letzte Stütze in der Humanität" [10. P. 636].
} 
"individual soul" came to be spoken of in Plato as a "living, rational organism acting according to concepts of purpose", which stands in interrelation with the "world soul" [13. P. 185]. The mythically dressed term from the dialogue Timaios appears enlightened by Cohen and transformed into the macrocosm of humanity. Thus, the narrower limits of the "macrocosm of the state", in which, according to Plato, "the soul of man, therefore his concept, his idea" is better recognized "than in the microcosm of the human individual" [14. P. 34] $]^{27}$, are expanded in a universal sense. The fact that the soul interacts with humanity can be demonstrated by the works of art.

\subsection{The reference of aesthetics to psychology}

\subsection{Feeling as a supporting soul capacity}

Logic and Ethics each tended towards the unity of consciousness (as a cultural consciousness), but were only able to realize it partially: this as a unity of moral self-consciousness, that as a unity of the problem of cognition. Only Aesthetics (1912) gave a new meaning to the "soul power of feeling" [11. P. 98]. The feeling accompanies the thinking, be it in a Eureka experience, or in the progress of knowledge as pleasure, be it in the hard work of complex research or formalities as unwillingness. The soul's capacity for feeling absorbs the difference between pleasure and displeasure "as character and content" [11. P. 97f.]; (cf. [10. P. 195]). As the part that only Aesthetics has brought to full discovery, it bears "the totality of soul power", if it is then conceived as a "feeling of life" [11. P. 96].

It also accompanies the will that rejoices in the success of a project that has begun or that rejoices in the ethical decisions that others have made. "A good action has happened, which is in itself only of interests to me, by no means because of its relationship to me in its successes for me. And yet I am seized by this supposed fact as if it concerned my life. And I must rejoice in this act of human power, which increases my own worth of living, my consciousness of this worth of living, so that I am filled with joy" [15. P. 527]. In art, after all, the "feeling ... is everything. This is the ultimate meaning of art; and aesthetics has to fathom and determine it according to its depth." [10. P. 635f.]

Thus, is not aesthetics already able to produce a "closed unity of consciousness" [12. P. 426], insofar as it proves to be "the love for the nature of man, for the unity of this nature in body and soul" ${ }^{28}$, precisely "that unity which art is able to produce in the form of man"? [12. P. 416] Considering that "the soul is not evident to itself"29, the visual arts in particular gave it "form" by presenting "the soul of man in his body". Thus, "the archetype of humanity ... rises in the true work of art" [11. P. 210].

\footnotetext{
${ }^{27} \mathrm{Cf}$. the interpretation by Cassirer in para. 4.1. (see part II of this essay).

28 "The pure feeling is the pure love for the nature of man, which is a part of the general nature ... Without this love art would not have arisen, and without it it cannot be continued. It is the primordial force of art" [11. P. 182f.]. Cf. [11. P. 199].

29 "Die Seele versteht sich nicht ... von selbst" [11. P. 297].
} 
In the constellation of the concepts of the beautiful, the sublime, and humor, pure feeling had gained its orientation, whereby "the beautiful is the foundation that can give and secure uniformity to the aesthetic task", while the sublime as a correlate of the beautiful is held in check by humor. If the validity of the ideals of the beautiful and the sublime were not maintained, man could not follow his destiny to orient himself to the higher. He would fall back to the level of the natural, where he has much in common with the animals. But if, on the other hand, he was to deny his natural, corporeal, or even one can say, his creature nature, he would also fall out of the polar tension into which the higher and lower limit of human nature binds him.

Humor helps to accept this tension and to live in it. It contributes to the fact that the beautiful person remains human, without having to be elevated to a god or goddess. Humor is also able to prevent the high ideals from leading to feelings of overstrain in those who do not correspond to them, or to contempt for those who are not as blessed by nature as others. Humor is the form of reflection of human love, which includes reality slightly lagging behind the ideals of the beautiful and the sublime.

Guided by the constellation of concepts of the beautiful, the sublime, and humor, Aesthetics has settled on the entire cosmos of the arts in order to prove this love in architecture, painting, music, and poetry: to the "nature of man" was added the "man of nature" - man in the world of space and time. "Pure feeling" was formed "into the pure consciousness of self-feeling" [12. P. 417] as a "fragile equilibrium", which turns once to "the side of knowledge, then to that of the will, and accordingly once in the moment of the sublime, once in that of humor. This does justice to the task of the beautiful, and subjectively to the task of the pure self " [12. P. 421], yet "the self ... is only the foundation, by no means the homogeneous increase of selfish individuality" [12. P. 419].

\subsubsection{The systematic limitation of aesthetics}

Thus, the sought-after unity of consciousness seems to have already been found in the aesthetic. But even here Cohen's mastery of fine distinctions proves itself. If one were to follow the illusion that an "aesthetic enthusiasm" has spread at all times - the illusion of the artistic fantasy of "exhausting and fulfilling the unity of consciousness ... because it takes in and absorbs knowledge and will, science and ethics" [12. P. 427] ${ }^{30}$ - then the inherent right of the other parts of the system would be curtailed. Even "scientific" and "moral consciousness" do not claim to "make out the unity of consciousness alone". [12. P. 426f.] In order to maintain the equality of the forces of the soul in their living interplay, psychology is still needed, even after aesthetics. It had to deal with the problem "of human knowledge and world experience [as well] as philosophical systematics" [Ibid.] in the context.

30 This would be the case, for example, if an "aesthetic education of the human race [des Menschengeschlechts]" [12. P. 430] was intended, without the same attention being paid to the formation of ethical and cognition — as if the aesthetic could absorb the others. 
Consciousness is more than "only the physiological resultant of the nervous forces" [12. P. 427], but also other than the spiritualist counter-thesis to this materialistic one. Body and soul are to be thought of as a unity, as the great works of art have already made them clear, without becoming headless. In "embodied subjectivity" (Thomas Fuchs), "the body of man is the body of his soul ... and ... the soul of man is the soul of his body"31. But the "head" of this "double soul" is psychology. And it has to do with "the consciousness of culture and its unity [in science, ethics and aesthetics]. Culture, however, is a problem of history, and not only one of normality and pathology of the nervous system" [12. P. 429].

Cohen restricts the claim to take "human knowledge and world experience" as seriously as the "philosophical systematics", but now immediately again by pointing out that "only the ideal concept of culture" can generate the sought-after unity, but not "anthropology" or ethnology ("Völkerkunde", as it is called in response to Kant). Orientation for this elementary distinction gives the logical concept of Allness: "The peoples always form only majorities, just as the man of anthropology is only a unity of these majorities. The unity of culture is based on the unity of the allness of man, on the unity of the human race, as humanity" [12. P. 429].

Empirically, this unity is not given, but always first brought about as a "hypothesis" to be realized in action; artistic creation is also at best proleptic with regard to this goal. The critical-idealistic thrust of the argument takes up the human concerns that were first elaborated and handed down by the Hebrew prophets ${ }^{32}$. Cohen translates them into problems of his systematic philosophy, the form of which opens up neither "to the rigidity of the deductive model" nor to the metaphor of architectonics, but to the "musical paradigm" of polyphony as the "resonance" of difference [23. P. 169, 172, 173]. Psychology would have taken shape in the metaphors of music.

\section{References}

[1] Holzhey H. Gott und Seele. Zum Verhältnis von Metaphysikkritik und Religionsphilosophie bei Hermann Cohen. In: Moses S, Wiedebach H, editors. Hermann Cohen's Philosophy of Religion: International Conference in Jerusalem 1996. Hildesheim/Zürich/New York: Georg Olms Verlag; 1997. P. 85-104.

[2] Cheng F. Über die Schönheit der Seele. Sieben Briefe an eine wiedergefundene Freundin. München: C.H. Beck Verlag; 2018.

[3] Mankell H. Treibsand. Was es heißt, ein Mensch zu sein. dtv Verlagsgesellschaft; 2017.

[4] McEwan I. Saturday. (trans. by Bernhard Robben). Zurich: Diogenes; 2005.

[5] Dierken J. Der Mensch und seine Seele. In: Scheliha A, Dierken J, editors. Der Mensch und seine Seele. Bildung - Frömmigkeit - Ästhetik. Akten des Internationalen Kongresses der Schleiermacher-Gesellschaft in Münster. September 2015, Berlin, Boston: De Gruyter; 2017. P. 1-7.

\footnotetext{
${ }^{31}$ See: Cohen's Die dramatische Idee in Mozarts Operntexten [24. P. 29].

${ }^{32}$ Cf. Cohen, Das soziale Ideal bei Platon und den Propheten (1916) [24. P. 297-335], and Cohen, Der ethische Monotheismus der Propheten und seine soziologische Würdigung (1917) [24. P. 495-501].
} 
[6] Barth U. Selbstbewusstsein und Seele. In: Zeitschrift für Theologie und Kirche. 2004; (101):198-217.

[7] Fuchs Th. Verteidigung des Menschen. Grundfragen einer verkörperten Anthropologie. Berlin: Suhrkamp Verlag; 2020.

[8] Fuchs Th. Sind psychische Krankheiten Gehirnkrankheiten? In: Vogeley K, Fuchs Th, Heinze M, editors. Psyche zwischen Natur und Kultur. Berlin: Pabst/ Parodos Verlag; 2008. P. 67-79.

[9] Cohen H. Logik der reinen Erkenntnis. Berlin: B. Cassirer; 1902. = Cohen H. Werke: in $19 B d n$. Bd. 6 [ed. by the Hermann Cohen Archive at the Philosophical Seminar of the University of Zurich under the direction of H. Holzhey and H. Wiedebach]. Hildesheim, Zurich, New York: Georg Olms; 1977ff. [I quote the $1^{\text {st }}$ edition (1902)].

[10] Cohen H. System der Philosophie. T. 2: Ethik des reinen Willens. Berlin: B. Cassirer; 1904. = Cohen H. Werke: in 19 Bdn. Bd. 7. Hildesheim, Zurich, New York: Georg Olms; $1977 \mathrm{ff}$.

[11] Cohen H. Ästhetik des reinen Gefühls. Vol. 1. Berlin: B. Cassirer; 1912. = Cohen H. Werke: in 19 Bdn. Bd. 8.

[12] Cohen H. Ästhetik des reinen Gefühls. Vol. 2. Berlin: B. Cassirer; 1912. = Cohen H. Werke: in $19 \mathrm{Bdn}$. Bd. 9.

[13] Cohen H. Platons Ideenlehre, psychologisch entwickelt. In: Cohen H. Werke: in 19 Bdn. Bd. 12 [Holzhey H, Wiedebach H, editors]. Hildesheim, Zürich, New York: Georg Olms; 2012.

[14] Cohen H. Der Begriff der Religion im System der Philosophie. Gießen: Töpelmann; 1915. [Reprint publishing house Dr. Müller; 2006].

[15] Cohen H. Religion der Vernunft aus den Quellen des Judentums. 1919; Frankfurt a.m.: Kaufmann; 1929. [reprint Wiesbaden: Fourier; 1978].

[16] Aristotle. De Anima. Leiden, New York: E.J. Brill; 1994.

[17] Plato. Phaidros, 246a-249d. [summed up by J. Disse]. In: Disse J. Kleine Geschichte der abendländischen Metaphysik. Darmstadt: Primus Verlag; 2001.

[18] Dober HM. Seelsorge bei Luther, Schleiermacher und nach Freud. Leipzig: Evangelische Verlagsanstalt; 2008.

[19] Freud S. Eine Schwierigkeit der Psychoanalyse. In: Freud S. Gesammelte Werke. Band XII. Werke aus den Jahren 1917-1920. Frankfurt a.M.: S. Fischer; 1947. P. 3-12.

[20] Holzhey H. Der systematische Ort der "Religion der Vernunft" im Gesamtwerk Hermann Cohens. In: Holzhey H., Motzkin G., Wiedebach H., editors. "Religion der Vernunft aus den Quellen des Judentums". Tradition und Ursprungsdenken in Hermann Cohens Spätwerk. Hildesheim: Georg Olms; 2000. P. 37-59.

[21] Simmel G. Der Begriff und die Tragödie der Kultur [1911, reprinted]. In: Konersmann R., editor. Kulturphilosophie. Leipzig: Reclam; 1996. P. 25-57.

[22] Cassirer E. Die "Tragödie der Kultur. In: Konersmann R., editor. Kulturphilosophie. Leipzig: Reclam; 1996. P. 107-139.

[23] Fiorato P. "In einer Schwebe zwischen Erkenntnis und Sittlichkeit". Über Hermann Cohens Polyphonie des Systems. In: Wiedebach H., editor. Die Denkfigur des Systems im Ausgang von Franz Rosenzweigs "Stern der Erlösung". Berlin: Duncker \& Humblot; 2013. P. 163-174.

[24] Cohen H. Werke: in 19 Bdn. Bd. 17 [Wiedebach H., editor]. Hildesheim/Zürich/New York: Georg Olms; 2002. 


\begin{abstract}
About the author:
Dober Hans Martin - PhD, Professor, Pastor, Faculty of Protestant Theology, University of Tübingen, Tübingen, Germany (e-mail: hmdober@gmx.de).
\end{abstract}

\title{
Сознание, тело и душа: набросок ненаписанной Когеном психологии
}

\author{
Ханс Мартин Добер $₫$ \\ Тюбингенский университет, \\ Germany, 72076, Tübingen, Liebermeisterstraße, 12 \\ \hmdober@gmx.de
}

\begin{abstract}
Аннотация. Современные подходы склонны понимать человеческое сознание как некий алгоритм, или же редуцировать человеческую субъективность либо к органически-естественным процессам, либо к социальному конструкту, обусловленному спецификой культуры. Все это становится серьезным вызовом для этического гуманизма, который, по-видимому, нуждается в новом обосновании и фундаменте. Как возможно постичь и отстоять концепцию воплощенной субъективности человека и его свободу действий? Каким образом мы можем мыслить единство мышления, воли и чувства, при этом не теряясь в различных специализированных способностях и удерживая фокус на личности как на находящейся в ясном сознании, ответственной и самодостаточной единице? Наконец, каким образом можно сохранить смысл понятия души, если это традиционное определение человеческой субъективности перестало употребляться, как будто скрывшись за горизонтом? В данном рассуждении представлена попытка найти ответы на эти вопросы с помощью Германа Когена, великого еврейского философанеокантианца. Для этого предлагается обратиться к его психологии, о которой он неоднократно высказывался, но так никогда и не представил ее в систематическом изложении. Первая часть исследования посвящена истолкования ранней когеновской интерпретации Платона как «первичной клетке» его психологии. Далее показано, каким образом Коген отвечал на возникшие в связи с его психологическими штудиями вопросы и затруднения в трех разделах его философской системы - логике, этике и эстетике, в связи с чем особое внимание уделяется также философии религии Когена. Самодвижение души и ее глубокая связь с человеческим телом можно понимать и объяснять из единства человеческой культуры, а также всеобщности человека.
\end{abstract}

Ключевые слова: сознание, душа, психология, Платон, Кант, единство человеческой культуры

\section{История статьи:}

Статья поступила 20.05.2021

Статья принята к публикации 11.08.2021

Для цитирования: Dober H.M. Consciousness with Body and Soul: An Attempt at Cohen's Never-Written Psychology // Вестник Российского университета дружбы народов. Серия: Философия. 2021. Т. 25. № 3. С. 420 - 435. DOI: 10.22363/2313-2302-2021-25-3-420-435

\section{Сведения об авторе:}

Добер Ханс Мартин - PhD, профессор, пастор, факультет протестантской теологии, Тюбингенский университет, Тюбинген, Германия (e-mail: hmdober@gmx.de). 